\title{
Л.П.Войтенко, О.Г.Ніконенко
}

\section{Модифікація експериментальної ротенонової моделі хвороби Паркінсона}

\author{
Інститут фізіологї ім. О.О.Богомольия НАН України, Київ, E-mail: agn@biph.kiev.иа
}

\begin{abstract}
Запропоновано модифікачію експериментальної моделі хвороби Паркінсона, щзо передбачає стереотаксичну інфузію розчину ротенону за допомогою оригінального пристрою у центральну зону компактної частини чорної субстаниї (ЧС) дорослих щурів лінії Вістар. Встановлено, що через 10 діб щільність дофамінергічних (ДА) нейронів у діляниі інфузії нейротоксину зменшується майже в

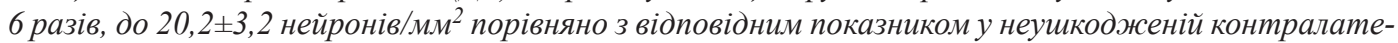

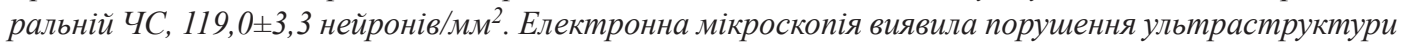
мітохондрій нейронів ЧС у зоні інфузії, щяо переважно обмежувалися дезорганізаиією крист у ици органелах. Відсутність загальної токсичності та селективність ураження тканини мозку свідчать про те, що запропонована модифікація моделі є адекватною та придатною для досліджень ефектів дегенераиії ДА-нейронів, притаманної хворобі Паркінсона у людини.

Ключові слова: ротенон; модель іп vivo; хвороба Паркінсона
\end{abstract}

\section{ВСТУП}

Дофамінергічні (ДА) нейрони середнього мозку беруть безпосередню участь у контролі моторних і когнітивних функцій головного мозку, які забезпечують довільні рухи та робочу пам’ять. Найбільш численні популяції ДА-нейронів локалізовані у чорній субстанції (ЧС) та вентральній тегментальній ділянці середнього мозку. Незважаючи на те, що проекції ДА-нейронів дуже різноманітні, ці клітини мають подібні молекулярні та електрофізіологічні характеристики [1]. Їх ураження у ЧС, що є типовою рисою хвороби Паркінсона, та його наслідки можна вивчати на тваринах в умовах експериментальних моделей. Такі моделі передбачають використання тварин генетично-модифікованих ліній [2], а також тварин, що були піддані дії таких нейротоксинів, як 6-оксидофамін [3, 4], 1-метил-4-фенілтетрагідропіридин [5], паракват [6] або ротенон [7, 8].

Ротенон - це флавоноїд, що пригнічує пе-

(c) Л.П.Войтенко, О.Г.Ніконенко ренесення електронів з Fe/S-центрів НАДНдегідрогенази на убіхінон, чим перешкоджає виробленню АТФ внаслідок окисного фосфорилювання. Водночас він не впливає на продукцію АТФ у процесах гліколізу [9]. При його дії ДА-нейрони гинуть через виникнення дефіциту енергетичного метаболізму. Цю речовину застосовували у попередніх дослідженнях для моделювання хвороби Паркінсона in vivo $[7,10]$ та in vitro $[11,12]$.

Більшість ротенонових моделей in vivo передбачає тривале системне введення цього нейротоксину у щурів $[7,8,10,13]$. Основні недоліки такого підходу - недостатня селективність ураження структур головного мозку $[7,13]$ та небажана токсичність ротенону, наприклад, щодо кардіоваскулярної системи [10]. У таких умовах досить важко отримати групу дослідних тварин з однотиповими ураженнями головного мозку [7]. Зокрема, відомі випадки, коли токсичний ефект ротенону, при його системному введенні, не призводив до дегенерації ДА-нейронів ЧС [13]. 
Мета нашої роботи - спроба розробити експериментальну модель, яка б дала змогу отримувати прогнозовані ураження ДА-нейронів ЧС, не мала ефектів загальної токсичності та була зручною для досліджень морфологічних змін тканини головного мозку, характерних для хвороби Паркінсона. За основу було взято модель, запропоновану Ксіонгом та співавт. [14], яка була модифікована для посилення ефекту дегенерації ДАнейронів у ЧС.

\section{МЕТОДИКА}

Досліди проведені на 39 дорослих щурах-самцях лінії Вістар масою 270-300 г. Зокрема, для імуногістохімічного аналізу використано 27 и для ультраструктурного - 12 тварин. Усі експерименти було виконано згідно з вимогами Європейської конвенції із захисту хребетних тварин (Страсбург, 1986). Ротенон („Sigma”, США) розчиняли у диметилсульфоксиді та вводили у дозах 6 або 12 мкг. Інфузію розчину здійснювали стереотаксично, в ліву половину головного мозку, у ділянку компактної частини ЧС. Для введення ротенону було застосовано пристрій на основі мікропіпетки Pipetman („Gilson”, Франція), що детально описаний у наступному розділі (рис. 1).

Перед операцією щурів наркотизували ін'єкцією суміші кетаміну - 50 мг/кг („Pfizer”, США) та ксилазіну гідрохлориду - 2 мг/кг (,Interchemie”, Нідерланди). Після цього тварин фіксували у стереотаксичному апараті (див. рис. 1, а). Через розріз поверхневих тканин відкривали доступ до поверхні склепіння їх черепа. Орієнтуючись на позначки брегми та лямбди (див. рис. 1, б), на поверхні черепа знаходили точку, що відповідала координатам AP 5,0 мм та L 2,0 мм за атласом [15], де робили отвір у кістці черепа. Голку інфузійного пристрою опускали через цей отвір, занурюючи їі у тканину мозку на відповідну глибину (DV 7,0 мм за атласом [15]) і повільно виштовхували з наконечника розчин ротенону у загальному об'ємі 1 мкл.

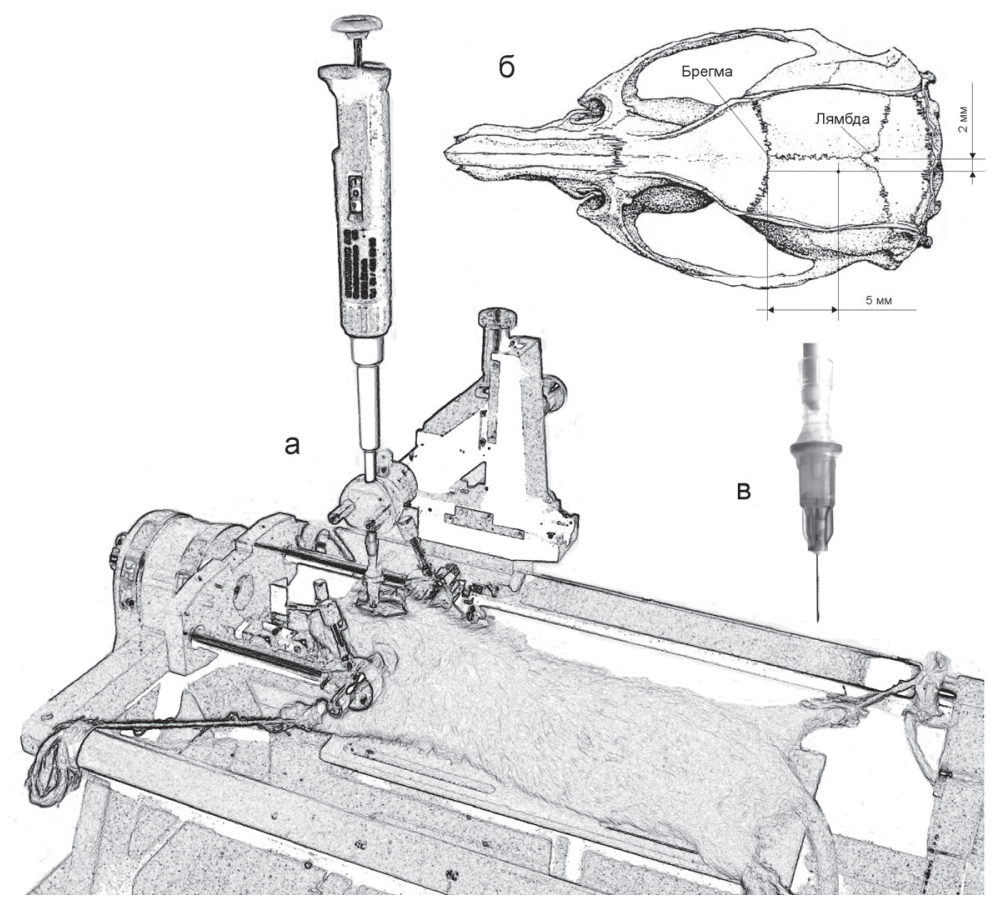

Рис. 1. Процедура проведення внутришньомозкової інфузії нейротоксину ротенону: $\mathbf{a}-$ загальний вигляд установки для внутришньомозкової інфузії ротенону; б - схема визначення стереотаксичних координат на поверхні черепа щура; B - наконечник мікропіпетки, що скомбінований зі стандартною голкою шприца 
Через 5, 10, 15 діб, або у віддалені періоди $-6,10,14$ тиж після внутришньомозкової інфузії ротенону, під глибоким наркозом щурів транскардіально перфузували 4\%-м формальдегідом на 0,1 моль/л фосфатному буфері (ФБ) (pH 7,4). Головний мозок кожної тварини додатково фіксували у 4\%-ному формальдегіді на 0,1 моль/л ФБ $(\mathrm{pH} 7,4)$ протягом однієї доби. Фронтальні зрізи головного мозку товщиною 50 мкм робили на вібратомі VT 1000 А („Leica”, Німеччина). Для ідентифікації нейронів і гліальних клітин використували подвійне імуногістохімічне пофарбування специфічними антитілами проти маркера нейронів NeuN (мишачі моноклональні, 1:1000, „Chemicon”, Великобританія), ключового ферменту ДА-нейронів тирозингідроксилази (ТГ) (мишачі моноклональні, 1:1000, „Sigma”, США) та маркера астроцитів GFAP (курячі поліклональні, 1:1500, „Dako”, Данія). Після промивання у 0,1 моль/л ФБ, зрізи обробляли вторинними антимишачими Alexa Fluor-555 (1:1000, „Invitrogen”, США), або антикурячими Alexa Fluor-647 (1:1000, „Invitrogen”, США) антитілами. Готові препарати аналізували у конфокальному мікроскопі FV 1000-BX 61 WI („Olympus”, США) 3 цифровою фотокамерою.

Для потреб електронної мікроскопії відповідну кількість щурів, через 6, 10 або 14 тиж після інфузії ротенону у ЧС, піддавали транскардіальній перфузії 4\%-м формальдегідом та 2,5\%-м глютаральдегідом, розчиненими у 0,1 моль/л ФБ (рН 7,4). Фронтальні зрізи головного мозку (товщиною 200 мкм) були зроблені на вібратомі та дофіксовані $1 \%$-м розчином $\mathrm{OsO}_{4}$ на 0,1 моль/л ФБ (рН $7,4)$. Далі зрізи зневоднювали та заключали у епоксидну смолу (Епон 812, „Sigma”, США). Тонкі зрізи тканини мозку товщиною 70 нм контрастували цитратом свинцю й уранілацетатом та аналізували у електронному мікроскопі JEM 100-CX („JEOL”, Японія).

Кількість життєздатних ДА-нейронів оцінювали як щільність ТГ-позитивних перикаріонів у зоні компактної частини ЧС. Як контроль використовували тканину відповідних контралатеральних ділянок мозку тих самих тварин, а також тканину несправжньо оперованих тварин, тобто таких, що отримували ін'єкцію 1 мкл розчинника без ротенону.

Ефективність операції контролювали за критерієм асиметричної поведінки тварин у Т-подібному лабіринті, що мав стінки 3 непрозорого матеріалу, через 2 тиж після операції. Реєстрували напрямок руху тварини в той чи іншій бік. Тест для кожної тварини повторювали 10 разів. Як контроль використовували несправжньо оперованих тварин.

Цифрові результати обробляли методами варіаційної статистики. Для порівняння вибірок використовували двобічний непараметричний критерій Колмогорова-Смирнова. Вірогідними вважали розбіжності при $\mathrm{P}<$ 0,05 .

\section{РЕЗУЛЬТАТИ ТА ЇХ ОБГОВОРЕННЯ}

Імуногістохімічне забарвлення проти ТГ дало змогу точно ідентифікувати ДА-нейрони. Ці клітини ми виявляли як перикаріони овоїдної, полігональної або веретеноподібної форми, 3 яких виходило 3-5 первинних дендрітів (див. рис. 2, а). Незважаючи на деякі варіації у діаметрі дендритів, більшість з них не були явно варикозними. На електронограмах нейрони компактної частини ЧС мали світлу цитоплазму 3 помірною кількістю мітохондрій еліпсоїдної форми. Ядро цих клітин було овальної форми, а ядерна оболонка мала інвагінації (див. рис. 2, б).

Відомо, що в середньому мозку знаходяться три 3 восьми груп ДА-нейронів, які ідентифіковані у межах головного мозку. Ці групи представлені взаємопов' язаними смугами, межі яких визначити важко. Група А8 вважається частиною ретикулярної формації середнього мозку та відома також як латеральна частина ЧС, в той час як група А9 повністю відповідає компактній частині ЧС. Еферентні проекції від клітин А8 та А9 груп завершуються у хвостатому ядрі та блідій кулі. 
Селективна втрата ДА-нейронів ЧС є характерною для хвороби Паркінсона у людини. Для відтворення цієї ситуації у щурів ми застосовували внутришньомозкову інфузію ротенону. Пристрій для цього був розроблений на основі механо-пневматичної мікропіпетки Pipetman („Gilson”, Франція) з регульованим об'ємом 1-20 мкл, змінний наконечник якої був зкомбінований 3 голкою шприца G27 $(0,4$ мм $\times 13$ мм) (див. рис. 1, в). Принцип дії мікропіпетки базується на всмоктуванні/ витисканні відповідної порції рідини, що здійснюється завдяки рухам плунжера у циліндрі. Мікропіпетка має вузол обмеження руху плунжера, який визначає робочий об'єм циліндра та, відповідно, кількість рідини, що всмоктується/витискається. Зменшення робочого об'єму за умови наявності рідини у наконечнику призводить до контрольованого ( з ціною поділки у 0,1 мкл) витискання рідини $з$ нього. У попередніх дослідженнях нами було обрано режим введення розчину роте- нону у загальному об' $є$ мі 1 мкл зі швидкістю 0,2 мкл/хв. Перед проведенням серії інфузій наконечник заповнювали розчином ротенону у об'ємі близько 20 мкл.

Для попередньої оцінки ефективності інфузії ротенону ми використали тест руху експериментальної тварини у Т-подібному лабіринті. Оскільки інфузія здійснювалась унілатерально, у ліву ЧС, вона могла вплинути на симетрію рухових реакцій у оперованих тварин. Тест проводили через 14 діб після операції у щурів, які отримували 6 мкг ротенону. Показано, що оперовані щури у $62,7 \pm 3,1$ \% випадків повертали у лабіринті в напрямку, контролатеральному до боку інфузії, тобто праворуч (рис. 3). Контрольні тварини робили аналогічний вибір лише у $53,0 \pm 2,5 \%$. Іншими словами, між двома групами щурів спостерігалися достовірні відмінності у ступені просторово-моторної симетрії.

В окремій серії дослідів вивчали динаміку ротенонзалежної унілатеральної дегенерації

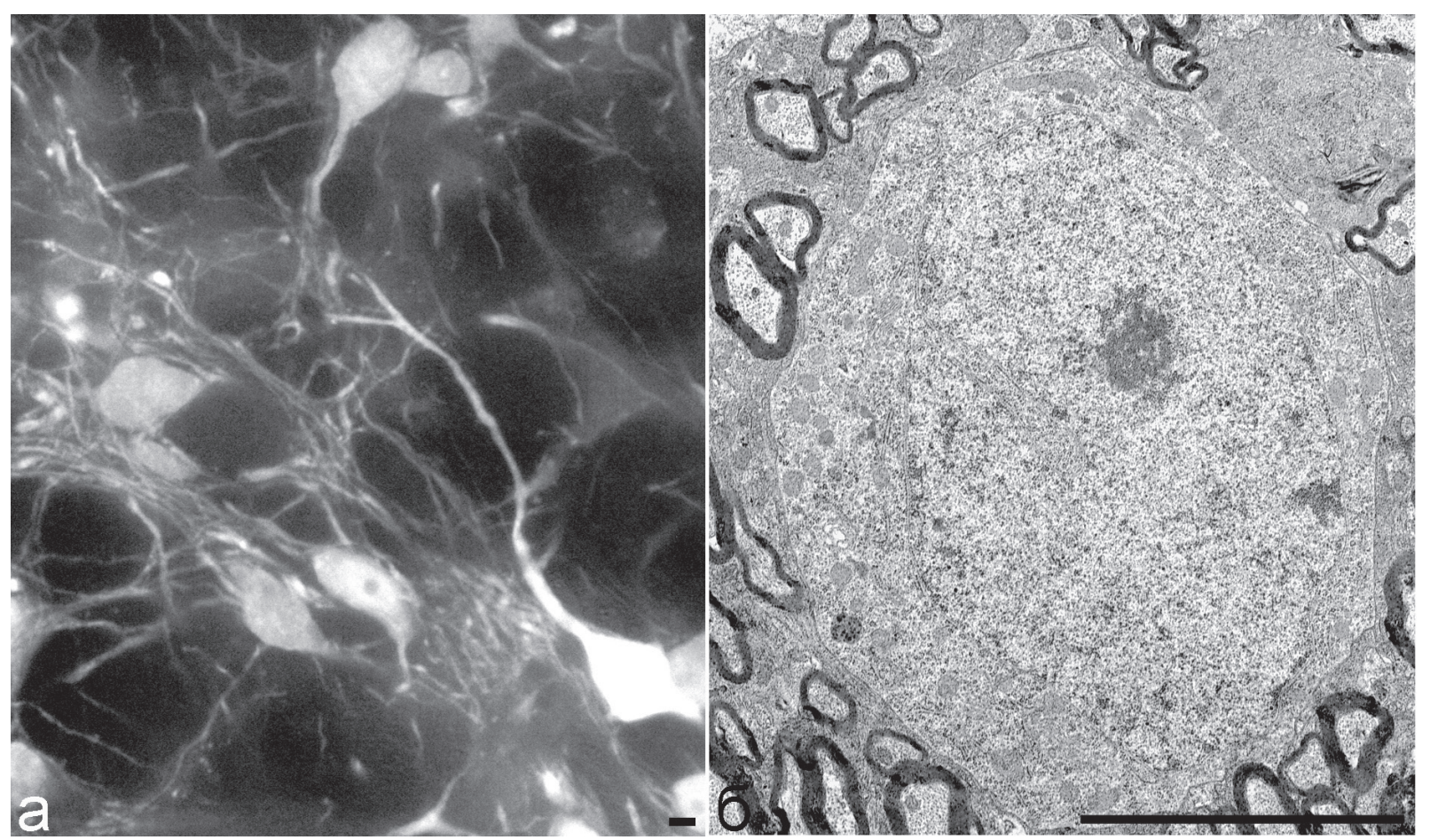

Рис. 2. Дофамінергічні нейрони чорної субстанції головного мозку щура: a - імуногістохімічне пофарбування на тирозингідроксилазу; б - електронограма тіла нейрона чорної субстанції. Масштабні лінії 5 мкм 
ДА-нейронів у ЧС. Оскільки ротенон є специфічним інгібітором окиснення субстратів ферментом НАДН-дегідрогеназою, він спроможний блокувати роботу електронно-транспортного ланцюга мітохондрій. Цей ефект ротенону є особливо цікавим у контексті моделювання геміпаркінсонізму у тварин тому, що порушення мітохондрій вважають спільною рисою широкого спектру нейродегенеративних захворювань, у тому числі і хвороби Паркінсона [16]. Дефіцит енергетичного обміну, викликаний нейротоксином ротеноном, має призводити до загибелі ДА-нейронів. Однак невідомою залишалася часова динаміка такої загибелі. Для з'ясування цього питання було досліджено тканину мозку відповідної кількісті тварин через 5, 10 або 15 діб після внутришньомозкової інфузії 6 мкг ротенону. На зрізах тканини мозку ДА-нейрони идентифікували за ознакою імунопозитивності до ТГ - ключового ферменту обміну дофаміну. Відомо, що цей фермент каталізує реакцію перетворення амінокислоти тирозину у діоксифенілаланін, який і є в свою чергу попередником дофаміну. Встановлено, що значна частка ДА-нейронів у зоні інфузії гине вже

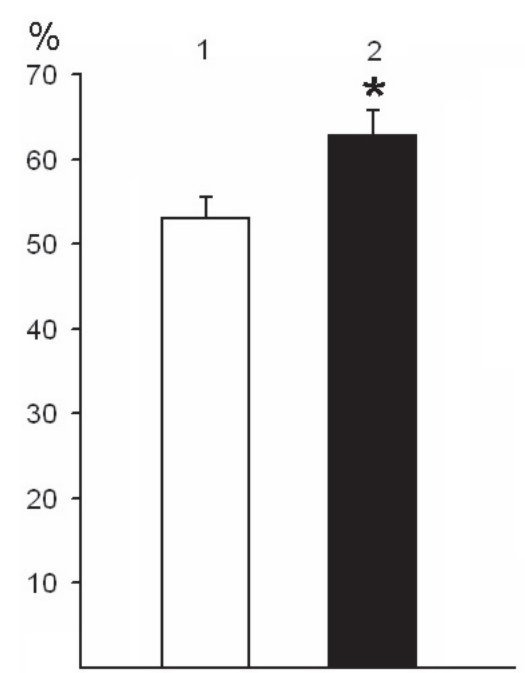

Рис. 3. Частота вибору напрямку руху (контралатерального щодо боку інфузії нейротоксину) у Т-подібному лабіринті через 14 діб після стереотаксичної інфузії 6 мкг ротенону. 1 - контроль, 2 - унілатеральна інфузія нейротоксину ротенону у чорну субстанцію. $* \mathrm{P}<0,05$ через 10 діб після внутрішньомозкової інфузії ротенону (рис. 4). Щільність ДА-нейронів у компактній частині ЧС зменшувалася майже в шість разів, до 20,2 $\pm 3,2$ клітин/мм² порівняно 3 відповідним показником у неушкодженій контралатеральній зоні, 119,0 3 ,3 клітин/ мм² $^{2}(\mathrm{P}<0,05)$. Порівняння мікрофотографій, наведених на рис. 4, а та б, дає змогу зробити попередній висновок про те, що внаслідок дії ротенону насамперед гинуть ДА-нейрони 3 перикаріонами великого розміру.

Слід зазначити, що морфологічний фенотип GFAP-позитивних клітин (астроцитів) у зоні інфузії ротенону через 10 діб після операції свідчить про їх підвищену активність. Астроцити мають більшу кількість відростків, які довші за такі у відповідних гліальних клітин у контролі. Зміни морфології астроцитів і посилення експресії ними GFAP вказують на активну участь цих клітин у процесах реорганізації тканини мозку після інфузії нейротоксину ротенону.

Середньострокову динаміку загибелі ДАнейронів вивчали у щурів, які отримували ротенон у дозах 6 або 12 мкг та були перфузовані через 6, 10 та 14 тиж після операції. Нами встановлено, що значне зниження кількості ТГ-позитивних клітин у ЧС було обмежено зоною інфузії, розмір якої варіював. Не було виявлено прогресивної динаміки загибелі цих клітин у більш віддалені строки після операції. Так, відмінності в кількості ТГпозитивних перикаріонів у зоні інфузії нейротоксину через 10 діб, 6, 10 та 14 тиж після операції були незначними. Крім того, не було виявлено дозозалежного ефекту ротенону. Таким чином, зона загибелі ДА-нейронів під впливом ротенону не розширюється $з$ часом, а доза нейротоксину у 6 мкг є достатньою для загибелі більшості ДА-нейронів та активації глії у ділянці інфузії.

У тварин, які отримували 12 мкг ротенону, вищезгадані зміни астроцитів у зоні інфузії нейротоксину через 6 тиж після операції були подібними до таких і через 10 діб. Але через 10 або 14 тиж після операції, морфологія 


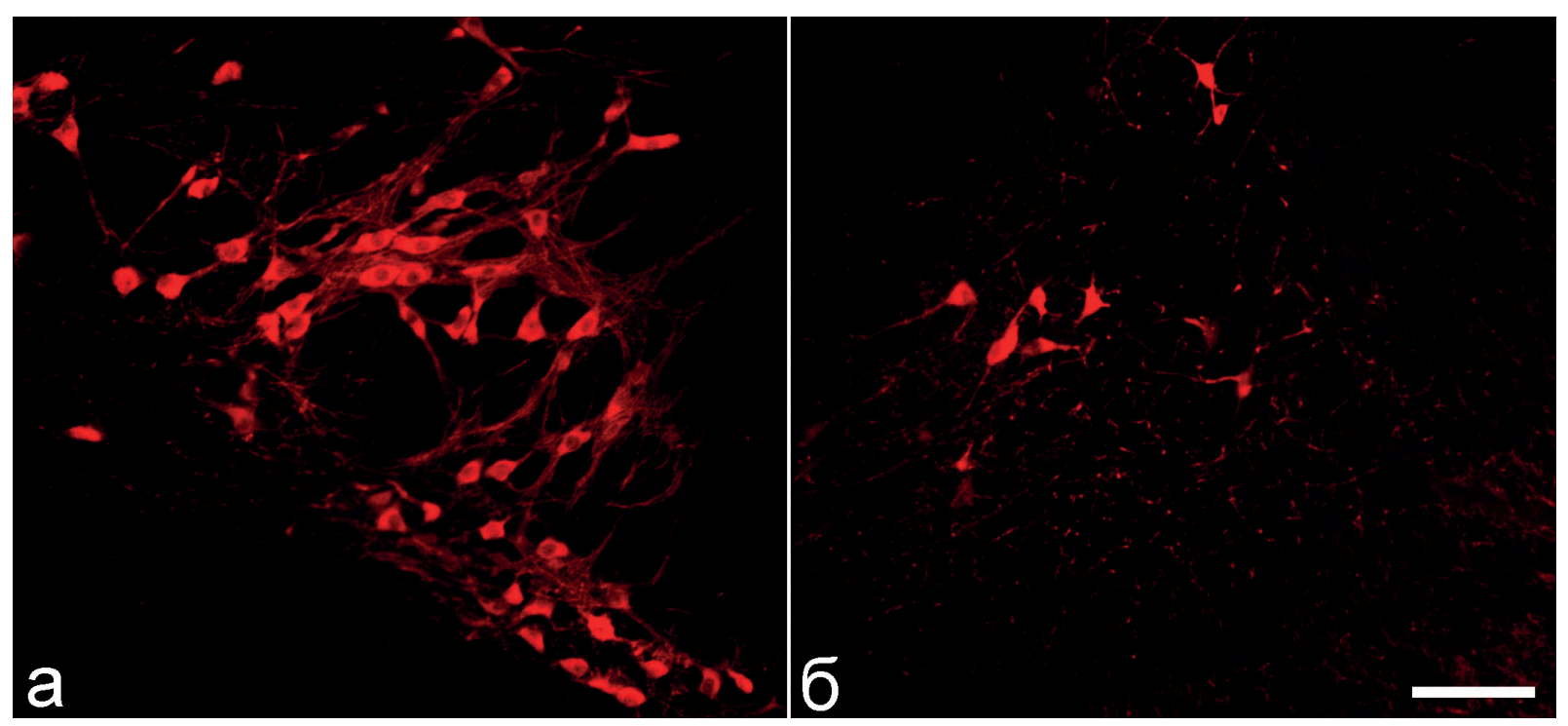

Рис. 4. Тирозингідроксилаза-позитивні нейрони чорної субстанції через 10 діб після унілатеральної інфузії 6 мкг нейротоксину ротенону: а - нейрони контрольної зони, що є контралатеральною до зони інфузії; б - нейрони у зоні інфузії ротенону. Масштабна лінія 100 мкм

астроцитів та рівень експресії ними GFAP у ділянці інфузії нейротоксину не відрізнялися від відповідних контрольних показників.

Гістологічне дослідження виявило ознаки дегенерації нейронів у ЧС та вентральній тегментальній ділянці після внутрішньомозкової інфузії ротенону, які були помітні вже через 6 тиж після операції. Дегенерація ДА-нейронів посилювалась у більш віддалені строки (рис. 5). Однак у ділянці гіпокампа ознаки нейродегенерації не спостерігалися.

Слід зазначити, що проведений електронно-мікроскопічний аналіз виявив порушення ультраструктури мітохондрій нейронів ЧС, що переважно обмежувалися дезорганізацією крист у цих органелах.

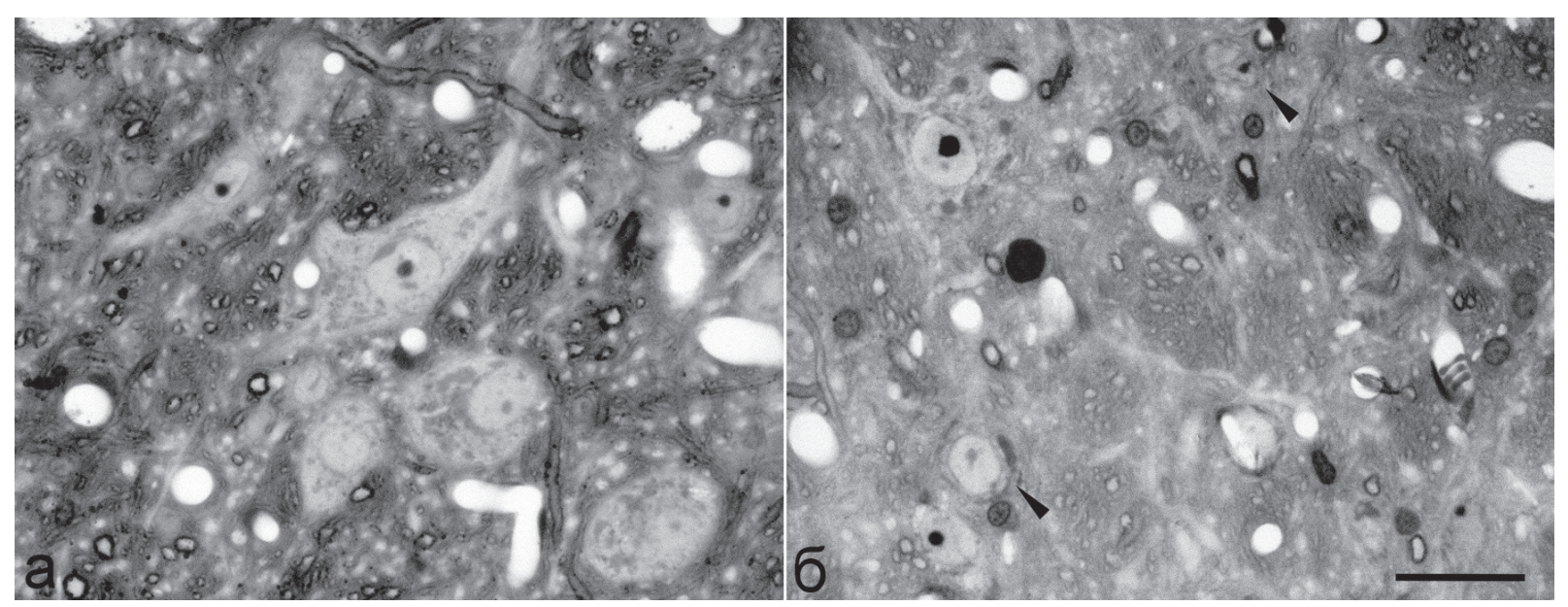

Рис. 5. Тканина чорної субстанції через 10 тиж після унілатеральної інфузії 6 мкг ротенону: а - нейрони у зоні, що є контралатеральною до зони інфузії; б - нейрони у зоні інфузії ротенону (стрілки вказують на нервові клітини з ознаками дегенерації). Масштабна лінія 25 мкм 
Переважна більшість ротенонових in vivo моделей хвороби Паркінсона передбачає тривале (від одного до декількох тижнів) системне введення токсину або за допомогою осмотичного мікронасоса, вживленого під шкіру [10], або через канюлю, під'єднану до шийної вени [13]. Технічно простіший варіант моделі використовує інтраперитонеальні ін'єкції ротенону (раз на добу) у дозі 2,5-3,0 мг/кг і протягом тривалого періоду [7, 8]. У разі використання осмотичного мікронасоса добову дозу нейротоксину підвищували до 12 мг/кг [10] або навіть до 18 мг/кг [13].

Незважаючи на те, що ці експериментальні моделі дали змогу отримати цікаві результати щодо розвитку дегенерації ДА-нейронів у головному мозку, було продемонстровано, що вони мають цілу низку обмежень. По-перше, системне введення ротенону не гарантує прогнозованого розподілу зон ураження у головному мозку. Так, втрати ДА-нейронів і гліозис можуть бути значними у строкатому тілі та блідій кулі, але не у ЧС [13]. Крім того, системне введення нейротоксина ротенона у великих дозах може призводити до небажаної токсичності [10].

У спостереженнях за оперованими тваринами не виявлено таких порушень поведінки, типових для ХП або для системного введення ротенону, як гіпокінезія та акінезія, ригідність, нестабільність пози $[7,8,10]$. Можливе пояснення базується на тому, що в умовах конкретної ротенонової моделі гинуть ДА-нейрони компактної частини ЧС лише з одного боку, в той час як клітини парної контралатеральної структури залишаються неушкодженими.

Відомо, що розвиток хвороби Паркінсона починається з появи агрегатів $\alpha$-синуклеїну у відростках нейронів кишечника та мотонейронів блукаючого нерва. Крім ЧС, тільця Леві також знаходять у блакитній плямі, ядрах шва, корі та інших структурах головного мозку [17]. Ми не змогли виявити відкладення $\alpha$-синуклеїну, що є характерними для хвороби Паркінсона. Однак слід зазначити, що такі відкладення у формі тілець та/або нейритів Леві 3'являються на розвинутих стадіях хвороби, коли загибель значної кількості ДА-нейронів стає очевидним фактом. Аналіз літератури вказує на те, що при системному введенні ротенону внутришньоклітинні $\alpha$-синуклеінові депозити виявляють не завжди $[8,10]$.

Отже, використана модель геміпаркінсонізму дає змогу відтворювати у щурів суттєві нейродегенеративні зміни, притаманні хворобі Паркінсона. Модель, яка передбачає стереотаксичні інфузії невеликих доз ротенону у зону ЧС, демонструє відсутність периферичної токсичності. Вона дає змогу відтворити повільну та специфічну втрату ДА-нейронів в обмеженій ділянці ЧС (pars compacta) та уможливлює імітацію окремих характеристик ідіопатичної ХП. Цей варіант ротенонової моделі відтворює такі зміни лише на боці інфузії нейротоксину ротенону. Електронна мікроскопія виявила також порушення ультраструктури мітохондрій нейронів ЧС у зоні інфузії ротенону, які переважно обмежувалися дезорганізацією крист у цих органелах.

\section{Л.П. Войтенко, А.Г. Никоненко}

\section{МОДИФИКАЦИЯ ЭКСПЕРИМЕНТАЛЬ- НОЙ РОТЕНОНОВОЙ МОДЕЛИ БОЛЕЗНИ ПАРКИНСОНА}

Предложена модификация экспериментальной модели болезни Паркинсона, которая предполагает стереотаксическую инфузию раствора ротенона с помощью оригинального устройства в центральную зону компактной части черной субстанции (ЧС) взрослых крыс линии Вистар. Установлено, что через 10 сут после такой инфузии плотность дофаминергических (ДА) нейронов в области инфузии нейротоксина уменьшается почти в 6 раз, до 20,2 $\pm 3,2$ нейронов $/ \mathrm{Mм}^{2}$, в сравнении с соответствующим показателем в неповрежденной контролатеральной ЧС, 119,0 $\pm 3,3$ нейронов/ мм² $^{2}$. Электронная микроскопия выявила нарушения ультраструктуры митохондрий нейронов ЧС в зоне инфузии, которые ограничивались главным образом дезорганизацией крист в этих органеллах. Отсутствие общей токсичности и селективность нарушений ткани мозга свидетельствуют о том, что предложенная модель адекватна и может применяться в исследованиях эффектов дегенерации ДА-нейронов, присущей болезни Паркинсона у человека.

Ключевые слова: ротенон; модель in vivo; болезнь Паркинсона. 
L.P. Voitenko, A.G. Nikonenko

\section{MODIFICATION OF EXPERIMENTAL ROTENONE MODEL OF PARKINSON'S DISEASE}

A modification of experimental model of Parkinson's disease is proposed presuming the stereotaxic infusion of rotenone solution using a special device into the cental part of substantia nigra (SN) pars compacta of adult Wistar rats. It was shown that 10 days after infusion of the neurotoxin the density of dopaminergic (DA) neurons in the infusion area drops nearly six-fold, to $20.2 \pm 3.2$ neurons $/ \mathrm{mm}^{2}$, with respect to the corresponding value in non-affected controlateral SN, 119.0 \pm 3.3 neurons $/ \mathrm{mm}^{2}$. Electron microscopy has shown ultrastructural impairments in mitochondria of SN neurons in the infusion area displayed mainly as a cristae disarray. The absence of overall toxicity and selectivity of the brain tissue impairments provide an evidence that the proposed rotenone model modification is adequate and can be used to study the effects of DA neuronal degeneration typical of Parkinson's disease.

Keywords: rotenone; in vivo model; Parkinson's disease.

O.O.Bogomoletz Institute of Physiology of National Academy of Sciences of Ukraine, Kyiv

\section{REFERENCES}

1. Roeper J. Dissecting the diversity of midbrain dopamine neurons. Trends Neurosci. 2013; 36(6): 336-42.

2. Abeliovich A, Schmitz Y, Farinas I, Choi-Lundberg D, Ho WH, Castillo PE, Shinsky N, Verdugo JM, Armanini M, Ryan A, Hynes M, Phillips H, Sulzer D, Rosenthal A. Mice lacking alpha-synuclein display functional deficits in the nigrostriatal dopamine system. Neuron. 2000; 25(1): 239-52.

3. Tkachenko MN, Zozulya IS, Shapoval MV, Sagach VF. Parkinsonism: current concepts of pathogenesis and the possible ways to correct. Ukr Med J. 2000; 3: 9-14.

4. Ungerstedt $U$. Striatal dopamine release after amphetamine or nerve degeneration revealed by rotational behaviour. Acta Physiol Scand Suppl. 1971; 367: 49-68.

5. Bloem BR, Irwin I, Buruma OJ, Haan J, Roos RA, Tetrud JW, Langston JW. The MPTP model: versatile contributions to the treatment of idiopathic Parkinson's disease. J Neurol Sci. 1990; 97(2-3): 273-93.

6. Bove J, Perier C. Neurotoxin-based models of Parkinson's disease. Neuroscience. 2012; 211: 51-76.

7. Alam M, Schmidt WJ. L-DOPA reverses the hypokinetic behaviour and rigidity in rotenone-treated rats. Behav Brain Res. 2004; 153(2): 439-46.

8. Cannon JR, Tapias V, Na HM, Honick AS, Drolet RE, Greenamyre JT. A highly reproducible rotenone model of Parkinson's disease. Neurobiol Dis. 2009; 34(2): 279-90.

9. Dickman KG, Mandel LJ. Differential effects of respiratory inhibitors on glycolysis in proximal tubules. Am J Physiol. 1990; 258(6): 1608-15.

10. Betarbet R, Sherer TB, MacKenzie G, Garcia-Osuna M, Panov AV, Greenamyre JT. Chronic systemic pesticide exposure reproduces features of Parkinson's disease. Nat Neurosci. 2000; 3(12): 1301-06.

11. Borland MK, Trimmer PA, Rubinstein JD, Keeney PM, Mohanakumar K, Liu L, Bennett JP Jr. Chronic, low-dose rotenone reproduces Lewy neurites found in early stages of Parkinson's disease, reduces mitochondrial movement and slowly kills differentiated SH-SY5Y neural cells. Mol Neurodegener. 2008; 3: 21.

12. Keeney PM, Xie J, Capaldi RA, Bennett JP Jr. Parkinson's disease brain mitochondrial complex I has oxidatively damaged subunits and is functionally impaired and misassembled. J Neurosci. 2006; 26(19): 5256-64.

13. Ferrante RJ, Schulz JB, Kowall NW, Beal MF. Systemic administration of rotenone produces selective damage in the striatum and globus pallidus, but not in the substantia nigra. Brain Res. 1997; 753(1): 157-62.

14. Xiong N, Huang J, Zhang Z, Zhang Z, Xiong J, Liu X, Jia M, Wang F, Chen C, Cao X, Liang Z, Sun S, Lin Z, Wang T. Stereotaxical infusion of rotenone: a reliable rodent model for Parkinson's disease. PLoS One. 2009; 4(11): e7878.

15. Paxinos G, Watson Ch. The rat brain in stereotaxic coordinates. New York: Academic Press. 2006: 456 p.

16. Itoh K, Nakamura K, Iijima M, Sesaki H. Mitochondrial dynamics in neurodegeneration. Trends Cell Biol. 2013; 23(2): 64-71.

17. Goedert M, Jakes R, Crowther RA, Spillantini MG. Parkinson's disease, dementia with Lewy bodies, and multiple system atrophy as $\alpha$-synucleinopathies. Methods Mol Med. 2001; 62: 33-59. 